\title{
Literarnozgodovinska in književnokritična refleksija madžarske književnosti po letu 1980 v slovenščini
}

\author{
Miran Š TUheC \\ Univerza v Mariboru, Filozofska fakulteta, Koroška cesta 160, \\ SI-2000Maribor,miran.stuhec@uni-mb.si
}

\begin{abstract}
Članek se ukvarja s problemom poznavanja sosednje književnosti oziroma sledi literarnozgodovinskemu in književnokritičnemu spisju, ki slovenskemu bralcu približuje madžarsko književnost. Glavne ugotovitve so tri: prvič, Slovenci so se z madžarsko književnostjo seznanjali že od začetka 20. stol. naprej; drugič, teh uvidov je manj kot bi glede na bližino obeh narodov, njuno povezanost in pomen same literature pričakovali, in tretjič, porast »slovenskega« interesa je opazen $v$ zadnjih letih.
\end{abstract}

The article considers the problem of the familiarity of the neighbouring literature and traces the literary-historical and the literary-critical writing that introduced Hungarian literature to the Slovene reader. There are three main findings: firstly, the Slovenes have been acquainted with Hungarian literature since the beginning of the 20th Century; secondly, there is less comprehension of it than could be expected, given the proximity of the nations, their connections and the importance of the literature, and thirdly, an increase in "Slovene" interest is noticeable in recent years.

Ključne besede: madžarska književnost, recepcijski horizont, razpršenost literarnega interesa, literarna kompetenca

Key words: Hungarian literature, reception horizon, dispersion of the literary interest, literary competence

1 Leta 2003 mi je moja magistrantka podarila antologijo sodobne madžarske kratke proze z naslovom Vzvalovano Blatno jezero. To je bil pravzaprav moj prvi resnejši stik s književnostjo sosednjega naroda. In takoj že tudi začudenje, kako blizu in daleč je lahko literarna praksa, ki nastaja v moji neposredni soseščini. V tem prispevku se ne bom ukvarjal z besedili, ki jih je urednik uvrstil 
v reprezentativno zbirko, ki naj tujcu pokaže, kaj se dogaja v sodobni kratki madžarski pripovedni prozi, ampak bo moj interes namenjen literarnozgodovinskim in literarnokritičnim uvidom $\mathrm{v}$ madžarsko književnost $\mathrm{v}$ slovenščini. Povedano z drugimi besedami, zanimalo me bo, $v$ kakšen recepcijski horizont je prišel omenjeni izbor. Ob tem se zavedam, da imajo o tem prvo besedo moji cenjeni kolegi z Oddelka za madžarski jezik in književnost mariborske Filozofske fakultete, a si kljub temu dovoljujem pogled literarnega zgodovinarja, čigar delo je sicer v veliki meri vezano zgolj na slovensko književnost, njegov interes pa sega tudi čez njene meje.

2 Izhodišče razprave je naslednje: o madžarski književnosti je bilo glede na njen obseg in bližino napisanega malo. Upoštevajmo pri tem, da gre za narod, ki se je s svojim več kot tisočletnim življenjem v srednji Evropi močno zasidral v zavesti svojih sosedov, zaradi prekmurske zgodovinske izkušnje še posebej pri Slovencih; gre za narod, ki ima bogato kulturno tradicijo in literarno izročilo ter ne nazadnje tudi Nobelovega nagrajenca za literaturo. Trditev o skopih vesteh posebej velja za prvo polovico prejšnjega stoletja. Seveda pa to ne pomeni, da Slovenci tudi v preteklosti nismo sledili temu, kar se je dogajalo pri vzhodnih sosedih. Prvi resnejši literarnozgodovinski zapisi so z začetka prejšnjega stoletja, ko je predvsem v Sombotelu živeči slovenski pesnik, jezikoslovec, urednik in prevajalec Avgust Pavel pisal o madžarski literaturi ter o kulturnih stikih med obema narodoma. Ob njem je potrebno omeniti še vsaj Vilka Novaka in Tineta Debeljaka, ki sta leta 1940 prevedla poetično dramo pomembnega madžarskega pisca Imreta Madácha Tragedija človeka (1861). Jože Filo v svoji študiji ${ }^{1}$ navaja tudi prevajalce Alojza Benkoviča, Branka Rudolfa, Cvetka Golarja, Franceta Bevka idr., ki da so vzdrževali stike s sosednjo književnostjo.

Po 2. svetovni vojni so se zapisi o madžarskem slovstvu nadaljevali s približno enakim tempom. To velja vsaj za čas do leta 1980. V tem obdobju je bil za slovenski literarni in širši duhovni prostor zanimiv, denimo, veliki pesnik Sándor Petöfi; ob tem ni presenetljivo, da ga je takratni kulturno-politični in predvsem ideološki kontekst želel videti predvsem kot pesnika madžarske revolucije. Res je, da se s takimi pogledi slovenski kritiki niso močno oddaljevali od dejanskega stanja, a je hkrati res tudi, da bi si veliki Madžar zaslužil še celovitejšo podobo, ki bi upoštevala tiste plasti njegovega opusa, katerih diskurz ga je približeval nekaterim velikim evropskim sodobnikom. ${ }^{2}$ Konec šestdesetih let in v sedemdesetih letih smo Slovenci dobili ob nekaterih krajših zapisih vsaj tri dobre uvide v madžarsko književnost - najprej, leta 1969 sta urednik Jože Hradil in pisec spremne študije Mihály Czine pripravila izbor petindvajsetih

${ }^{1}$ Jože Filo je leta 1992 v Zborniku slavističnega društva objavil dve razpravi Slovenci in madžarska književnost in Kratek oris madžarske književnosti ter z njima pripravil zanesljiv uvid $\mathrm{v}$ imenovano problematiko.

${ }^{2}$ Delno se je od konceptov, ki so veljali v slovenski literarni zgodovini v desetletjih po drugi svetovni vojni, leta 1974 v spisu 150-letnica Petöfijevega rojstva oddaljil Štefan Barbarič. 
pripovednikov z naslovom Ljubezen, Izbor iz sodobne madžarske proze, nato je leta 1974 Orsolya Gállos v Sodobnosti objavila razpravo Madžarska lirika 60-ih let, tri leta kasneje pa sta urednika Kajetan Kovič in Jože Hradil, slednji je napisal tudi spremno študijo, pripravila reprezentativno knjigo Madžarska lirika 20. stoletja. ${ }^{3}$

Zadnja dobra tri desetletja, torej obdobje literature, natančneje pripovedne proze, ki jo je v literarnozgodovinskem smislu zajela na začetku imenovana antologija madžarske kratke proze, se od pravkar shematično opisane situacije iz prvih sedmih desetletij 20. stoletja pravzaprav bistveno ne razlikujejo. Informacij je sicer več, tudi njihova vsebina je popolnejša in objave razpršene po več časopisih, revijah in kot spremne besede v knjižnih izdajah. ${ }^{4}$ Ni pa se zgodilo nič posebno novega $\mathrm{v}$ vsebinskem smislu; kljub nekaterim odličnim študijam, zanimivim intervjujem ali poučnim opisom gre $\mathrm{v}$ glavnem za fragmentarne vpoglede - poročila, kratke ocene in kritike. Ta ugotovitev je še očitnejša, če pomislimo, da so bili madžarski ustvarjalci petkrat med dobitniki nagrade vilenica in kristala vilenica (Péter Eszterházy, 1988; Lajos Grendel, 1991; Endre Kukorelly, 1992; Péter Nádas, 1998; Vörös Istvan, 2000 in Pál Závada, 2002) 5 ter je leta 2002 Nobelovo nagrado za literaturo prejel Imre Kertész. Celovite literarnozgodovinske razprave, recimo monografije o madžarski književnosti, tega, kar bi bilo bistveno za relevanten uvid v madžarsko slovstvo, Slovenci žal še vedno nimamo. To trditev pa moram vendarle vsaj nekoliko omiliti: uspehi madžarske književnosti na vileniških srečanjih in, seveda, Nobelova nagrada so zanimanje predvsem za pripovedno prozo in poezijo vzhodnih sosedov povečali. Poglejmo, kaj se je v tem pogledu zgodilo v zadnjih dveh desetletjih.

Prevajalka in poznavalka madžarske književnosti Marjanca Mihelič je za revijo Literatura oziroma za njeno rubriko Blitzkrieg leta 1994 pripravila članek Madžarska proza devetdesetih. V njem je poučno in deskriptivno, manj pa analitično pisala o t. i. novi madžarski prozi, katere glavna značilnost je na eni strani upor zoper politično-literarne direktive in na drugi subjektivizacija, uvajanje novih narativnih postopkov ter funkcionalizacija forme. Avtorica se sprašuje o razliki med novo in najnovejšo prozo in pokaže, da sta madžarska kritika ter literarna zgodovina opazili predvsem fragmentarizacijo, minimalizem, širok fantazijski horizont, esteticizem, dalje primanjkljaj na ravni zgodbe (Endre Kukorelly, Gábor Németh) pa spet njeno potenciranje (Parti Nagy, László Darvasi), medbesedilnost ter interes za različne subkulturne prakse (Attila Hazai). Po uvodnem delu Miheličeva opozori na pomen literarne periodike, ki je socializirala nove književne tokove in njihove predstavnike, ter na izbiro književne uspešnice pri reviji Magyar Napló. Tu sta bila leta 1992 in

\footnotetext{
${ }^{3}$ Več o navedenih delih v Slovenci in madžarska književnost Jožeta Fila.

${ }^{4} \mathrm{~K}$ povedanemu je treba dodati, da so leta po 1980 pomenila opazen zagon slovenskega zanimanja za tuje književnosti nasploh (revije Sodobnost, Literatura in Nova revija) ter se je interes za madžarsko slovstvo realiziral znotraj teh tendenc.

${ }^{5}$ Nagrada vilenica: Péter Eszterházy in Péter Nádas, kristal vilenice: Endre Kukorelly, Vörös Istvan in Pál Závada.
} 
1993 nagrajena klasika madžarske povojne književnosti Géza Ottlik in Adám Bodor. Avtorica še na kratko povzame glavne značilnosti nagrajenih romanov Buda in Rajon Sinistra. V prvem delu članka spregovori prav tako o Miklósu Mészölyju, ki da je v 60-ih in 70-ih letih 20. stoletja v madžarsko literaturo uvajal obliko novega romana, eksistencializem, prvine nadrealizma in absurda. Kritiko in literarno znanost je po avtorici »osupnil« László Krasznahorkai, pripovedovalec zla, ničevosti sveta in človeka ter skrivnostnega kozmosa in ustvarjalec specifičnega jezika ter stroge tektonike. Miheličeva ob bok Krasznahorkaiju postavi Lászla Mártona, pisca obsežnega potopisnega romana Prehod skozi steklo, »hermetične umetnine«, kjer se prekrivata dve resničnosti, recepcijo pa otežujejo postmodernistični triki, denimo eklektične zveze, persiflaža, kopičenje citatov, mitologizacija, medbesedilnost, mnogopomenskost ipd. Miheličeva na koncu nekaj besed nameni še Attilu Hazaiju, Lászlu Garacziju in Gáboru Némethu.

Zanimiv članek o socialnem in sociološkem vidiku madžarske književnosti, o tujih vplivih, prevajalski politiki in o založništvu, katerega avtor je ameriški profesor Robert Murray Davis, je leta 2001 pod naslovom Položaj madžarske literature devetdesetih izšel v ugledni slovenski reviji Sodobnost. Prispevek ob madžarskem primeru pokaže na resne probleme, s katerimi se soočajo literarne sfere v nekdanjih socialističnih državah.

V Sodobnosti, ta je pravzaprav ves čas svojega izhajanja tujim slovstvom namenjala vidno pozornost, je istega leta izšla daljša razprava Zsolta Farkasa Sodobna madžarska proza. Avtor je za potrebe revijalne rubrike Predstavljamo pripravil pregled dogajanja v madžarski pripovedni prozi po letu 1980. Njegovo izhodišče je ugotovitev, da je madžarska književnost sredi osmega desetletja doživela globoke spremembe. To se je zgodilo, ko se je glavni tok literarne dinamike od etičnega diskurza preusmeril k estetskemu, s tem prekinil politično-ideološke pritiske in evociral tendence, ki so bile dolgo časa potisnjene ob rob dogajanja. Ključnega avtorja vidi v tudi pri nas dobro znanem in nagrajenem Pétru Eszterházyju. Širše literarnozgodovinsko ozadje pa najde v tradiciji Nyugata in Újholda, ki je že na začetku 20. stoletja na konceptu apolitične drže zagovarjala elitistično in k esteticizmu usmerjeno umetnost. Ta literarna ustvarjalnost je pomenila živo in plodno prevzemanje evropskih modernizmov ter njihovih kasnejših neomodernističnih variant in je bila pravzaprav res lahko naravna zveza med tradicijo ter sodobnostjo. Farkas potem navaja spodbude, prihajajoče iz ljudske književnosti, ki da se je s svojim izrazito nacionalnonarodnostnim sporočilom vključila v kulturno in socialno prenovo Madžarov, ter vplive socrealizma - ta je tako kot v drugih socialističnih državah pomenil ideološko, za samo umetnost neproduktivno vsiljevanje posebnih in z estetskega vidika nesprejemljivih kriterijev. Za razumevanje dinamike obravnavanega slovstva je pomembno, da Farkas vsaj nekoliko podrobneje razloži t. i. ljudsko gibanje, ki se je v tridesetih letih 20. stol. cepilo v več tokov, njihova dejavnost pa je variirala od poudarjanja socialnih tem, simpatiziranja s kasnejšo socialistično oblastjo, neposrednega nasprotovanja aktualni politiki do odkritega antisemitizma in etnocentrizma. Nastanek t. i. »Pétrove paradigme« (Péter 
Esterházy, Péter Nádas, Péter Hajnóczi idr.) je pomenil po avtorjevem mnenju pomemben vpliv ne le zato, ker je promoviral novo generacijo, ampak tudi, ker je reaktiviral nekatere starejše književnike (Jánosz Pilinszky, Iván Mándy idr.). Po prvem sintetično-uvajalnem delu se Farkas posveti posameznim pripovednikom, rojenim $\mathrm{v}$ petdesetih letih prejšnjega stoletja. Najprej predstavi pesnika in pripovednika Endreja Kukorellyja. Označi ga kot ustvarjalca z dobrim občutkom za jezikovnoslogovne možnosti, za pesnika in pripovednika, ki je s specifično poetiko svojih zgodnjih del, kjer se namenoma približuje profanemu, celo prostaškemu, degradiral takratni esetski kanon. Tudi kasneje, ko je njegov jezik izgubil izzivalni naboj, je Kukorelly zanimiv za madžarsko književno kritiko - po Farkasevem mnenju iz treh razlogov: prvič zato, ker so njegova dela interpretativno bogata, drugič zaradi sposobnosti resne teme subtilno nadgraditi s humorjem. Tretji vzrok je pisanje esejev in kritik o umetnosti, ženskah, o jeziku, nogometu itn., s čimer pisec uveljavlja svojevrstno problemsko in jezikovno ter slogovno prekrivanje različnih žanrov, poezije, proze in eseja. Drugi v avtorjevem izboru je pesnik, pisatelj in dramatik Parti Nagy, ki je jezikovno bogato in slogovno inventivno pisal o sobivanju različnih kultur, socialnih slojev, o komercializaciji in ekonomski logiki ter s tem reflektiral aktualno madžarsko problematiko 80-ih let. Avtor vidi v Partiju Nagyu ustvarjalca subtilne poetike in zgoščenega izraza, bogate metaforike in prefinjene ironije. Pisec se nato ustavi še pri estetiki fingiranega diletantizma in ob socialnem čutu ter humanizmu. László Garaczi, pripovednik in pesnik, prav tako sodi v generacijo, ki ji avtor po eni strani pripisuje poseben občutek, $\mathrm{s}$ katerim evocira zelo različne in nasprotne plasti madžarskega jezika, po drugi strani pa izpostavi radikalno nasprotje vsemu, kar bi omejevalo svobodno ustvarjalnost. László Garaczi je avtorju Zsoltu Farkasu književnik z občutkom za človeka, ustvarjalec distance in bližine, odsotnosti ter prisotnosti, domačnosti in transcendence. Zadnji je Gábor Németh, pisatelj, ki posebno pozornost posveča tehniki pripovedovanja. Farkas pravi, da je ta pisatelj sposoben prefinjene, čutne in rafinirane deskripcije na videz nepomembnih, a vendarle ključnih dogodkov, ti po sistemu fragmentarne strukture tvorijo vtis, da se v zgodbi ne dogaja nič senzacionalnega, kljub temu pa bralec sledi diskurzu nenehne napetosti med urejenim, domačim in svetim na eni strani ter relativnim, grozavim in brezbrižnim na drugi. V prepadu med obema skrajnostma nastaja diskurz o človekovem zavedanju samega sebe. Zsolt Farkas študijo zaključuje z ugotovitvijo, da imajo obravnavani avtorji na mlajše pisce celo močnejši vpliv kot obe slavni imeni madžarske literature Péter Eszterházy in Péter Nádas.

Revija Apokalipsa je leta 2004 objavila članek v Parizu delujočega madžarskega literarnega zgodovinarja in kritika Endreja Karátsona Komu pišemo? Avtor v njem razpravlja o možnostih, pomenu in interesih prevajanja madžarske književnosti v tuje jezike, o promociji ter morebitnih medkulturnih in medliterarnih stikih. Še posebej ga zanima dostopnost književnosti v tujem okolju, težav ne vidi le v ustreznosti prevodov oziroma prevajanja, ampak predvsem v različnosti kulturnih, zgodovinskih in civilizacijskih kontekstov. 
V časopisu Delo pa je leto kasneje z dobitnikom najvišjega madžarskega priznanja za prevajanje Pro Cultura Hungaricis Jožetom Hradilom izšel kratek intervju Tudi med manj znanimi so odlični pisatelji. V njem je poudarjeno dvoje: da je $\mathrm{v}$ slovenščino prevedenih razmeroma malo književnih del in drugič, da sosednja literatura ob svetovno znanih piscih premore več sicer manj vidnih, a vendarle odličnih ustvarjalcev. Izpraševanec na kratko predstavi nekatere med njimi: Sándorju Máraiju (Dnevniki; Zemlja, zemlja) pripiše enciklopedično znanje in sposobnost odličnega povezovanja različnih usod v vznemirljivo zgodbo, István Örkény (Tatovi; Mačja igra) je avtor duhovitih nadrealističnih pripovedi in satir na komunistični režim. Magda Szabó v Vratih ustvari prepričljivo pripoved o naravni modrosti in izkušenosti sicer čisto neizobražene ženske, Péter Nádas in Péter Esterházy pa sta po Hradilovem mnenju "ponovno zablestela«, prvi s Knjigo spominov, drugi s Harmonio Caelestis in Popravljeno $i z$ dajo. Med navedenimi madžarskimi literati je intervjuvanca najbolj vznemiril Sándor Tar s Počasnim tovorom, izpovedjo, ki je »bogat, večplasten, socialno pretresljiv skupek občutij«.

3 Drugi del mojega prispevka, ki naj pojasni, koliko in kakšne sledi je pustila madžarska literatura $\mathrm{v}$ slovenskem prostoru, namenjam vprašanju, kaj se je $\mathrm{z}$ obravnavanega vidika dogajalo s posameznimi madžarskimi književniki oziroma koliko so bili prisotni v zadnjih letih. Natančneje rečeno, zanimalo me bo, kdaj, ob katerih priložnostih je bilo o njih kot posameznikih napisanega največ in kateri med njimi so bili najpogosteje omenjani. Seveda prevelikih špekulacij tu ne more biti, vendarle je treba upoštevati vsaj dve dejstvi: prvo je Vilenica in nagrade, ki so jih tam prejeli madžarski pisci, drugo Nobelova nagrada, ki jo je leta 2002 dobil Imre Kertész. Že bežen pregled pove, da so Slovenci največkrat pisali o Pétru Esterházyju, Imretu Kertészu, Enreju Kukorellyju in Pétru Nadásu oziroma o tistih književnikih, ki so se še posebej odlikovali v slovenskem in evropskem prostoru. Najpomembnejši posredovalci madžarske književnosti v Slovenijo so Marjanca Mihelič, Jože Hradil in Mladen Pavičić, $\mathrm{v}$ zadnjih letih pa $\mathrm{v}$ slovenskem tisku o madžarski književnosti največ piše Jutka Rudaš.

Marjanca Mihelič je v Novi reviji leta 1992 poleg prevoda odlomkov Hrabalove knjige objavila tudi pogovor s piscem romana Pétrom Esterházyjem. Članek nosi naslov Vodnik po Esterházyju. Avtorica pisatelja sprašuje po morebitnem globljem pomenu kompozicije in ga skuša navesti na funkcionalno zvezo med formalnimi in vsebinskimi poudarki Hrabalove knjige. On pa ji odgovarja, da tektonska zgradba ${ }^{6}$ nima globljega pomena, in poudarja, da mu je šlo predvsem za pripovedovanje, kjer je prek združevanja fakta in fikcije želel razkriti aktualne politične razmere na eni strani in pisateljsko vizionarstvo na drugi. Istega leta je v Delu Jože Hradil objavil intervju z Endrejem Kukorellyjem Pesnik kot

\footnotetext{
${ }^{6}$ Roman je razdeljen na tri dele, tudi vsako poglavje je iz treh enot, srednje tudi razpade na tri dele; opazna je še tridelna struktura dneva.
} 
pesnik in državljan. Pogovor je potekal po koncu mednarodnega pisateljskega srečanja Vilenica, kjer je Kukorelly za pesem $\operatorname{Izhod}^{7}$ prejel kristal vilenice. Na vprašanje o zvezi med pesnjenjem in politiko je madžarski pesnik odgovoril, da politiko sicer redno spremlja, a ostaja njegovo pesniško delo zunaj nje. Kukorelly sicer ne izključuje možnosti, da je lahko družbeno dogajanje predloga umetniškemu ustvarjanju, a istočasno pove, da utegne biti za umetnika nevarno, če se obe področji prekrivata. Intervjuvanec izpostavi še to, da je po spremembi političnega sistema za kulturo denarja manj, a je ustvarjalno ozračje zaradi sproščenosti in svobode boljše. To sta po njegovem pridobitvi, ki zadevata človeka v ontološkem smislu, ne samo v umetniško-ustvarjalnem.

Naslednji pogovor s pomembnim madžarskim ustvarjalcem je objavila Gabriela Gaal leta 1996 v Delu. To je bil intervju s Pétrom Nádasem z naslovom Ali ima svet svojo konstrukcijo ali je kaos? Iz njega bralec izve, da si madžarski književnik prizadeva svet videti kot celoto, ne kot fragmentarizirani kaos, da želi ujeti, kar je na robu zavesti, in ga zanima, kaj se nahaja v preseku razuma, izkustva in domišljije, kaj je s preteklostjo in kakšna je njena podoba z vidika aktualnega trenutka. V smislu distance do zgodovine Nádas spregovori o svoji vzgoji, starših, politični diktaturi in se zaveda, da bi bilo njegovo pisanje drugačno, če bi živel v demokratičnem svetu. Tako razloži tudi svoja zadnja dela, v katerih prek zgodovinske in politične perspektive odsevajo povezave med antropološkimi, fillozofskimi, psihološkimi, političnimi in zgodovinskimi pojavi. Druga tema, ob kateri se ustavi Gaalova, je vloga telesnosti, spolnosti in homoseksualnosti. Na vprašanje o morebitni provokaciji Nádas odgovori, da je madžarska poezija nasploh erotična, proza pa iz ideoloških razlogov usmerjena k družbeno-političnim temam. Intervju vključuje še nekatere premisleke o slogu in jeziku ter o razmeroma pogostem motivu smrti.

Leta 1999 je Marjanca Mihelič k prevodu romana Pétra Nádasa Konec družinskega romana napisala spremno besedo. V njej Madžara umesti med pisatelje »nove proze«, ki jo zanimajo urbani pojavi in ignorira politično mišljenje v književnosti, pisateljevo delo Knjiga spominov pa postavi v vrh te proze. Avtorica podrobno predstavi Nádasevo življenje in opozori, da so židovstvo, komunistična pripadnost staršev pa njihov spor z madžarsko oblastjo, špijonaža, materina smrt in očetov samomor globoko zaznamovali ustvarjalčevo življenje in delo. Potem razloži različne odzive na pripoved Konec družinskega romana, na negativne ocene madžarskih kritikov in politikov ter na velik uspeh v tujini. Miheličeva ugotavlja, da so vzroki za tako situacijo v delu samem, ki jasno pokaže, kako sistematično se je politični sistem zajedal v vse pore javnega in zasebnega življenja in povzročal osebne tragedije, zgodnja spoznanja in neizbrisljiva občutja že v otroku. Dalje izpostavi pester simbolni svet romana, v katerem najde mitske zgodbe, legende, parabole, biblijske slike in simboliko krščansko-židovskega sveta ter ugotovi, da ima našteto izjemno interpretativno vrednost in omogoča večplastnost pomenov. Miheličeva izpostavi še pripovedni

\footnotetext{
${ }^{7}$ Pesem je bila izbrana za najboljši literarni prispevek v zborniku Vilenica 92.
} 
način, ki da je svoboden niz asociacij, stavek pa slogovno subtilna in ritmizirana struktura semantičnih zvez. Končno se avtorica ustavi pri romanu Knjiga spominov (1986). Tudi zdaj ugotavlja sintezo antropoloških in zgodovinskih tem ter pisateljeve osebne izkušnje, ki razkrivajo več generacij židovske družine na Madžarskem. Spremna beseda Marjance Mihelič je brez življenjepisnega dela z naslovom Roman lanskoletnega vileniškega lavreata v slovenščini istega leta izšla tudi v Delu.

V tem časopisu je leta 2000 Jutka Rudaš objavila prispevek Slovenija $v$ Nebeški harmoniji Esterházyjevih in v njem predstavila Esterházyjev roman Harmonia Caelestis. Po nekaj biografskih podatkih avtorica pove, da je roman nastal na presečišču zgodovine in fikcije, kjer se križata pogled v preteklost in zazrtost $\mathrm{v}$ prihodnost, ustavi se ob pripovedni tehniki in njenih slogovnih učinkih ter namigne na postmodernističnost njegove poetike.

V letu, ko je Imre Kertész prejel Nobelovo nagrado za književnost, torej 2002, je Aleksander Zorn v Delu objavil članek z naslovom Slavni madžarski pisatelj in v njem na kratko opisal življenje madžarskega nobelovca. Zorn Kertesza uvršča med najbolj presunljive pričevalce o holokavstu. Tema se avtorju najpregledneje kaže v »trilogiji o brezusodnosti«, ki jo sestavljajo romani Brezusodnost, Molitev za nerojenega otroka in Fiasko. Pisec v nadaljevanju predstavi tuje poglede na nagrajeni roman in svoje razumevanje Kertészovega besedila ter poudari, da gre $\mathrm{v}$ njem za krhko razmerje med posameznikom in zgodovino ter za dilemo, ali je mogoče delovati ter misliti individualno v času, ko so ljudje popolnoma podrejeni barbarski politični moči. Zorn Kertészu dodeli mesto med pisci pričevanjske literature, ki estetsko dognano spregovori o popolnem ponižanju človeka - ne le v totalitarističnih političnih sistemih, ampak tudi sicer. Tudi v sodobnem svetu, ki po padcu starih ideologij ostaja prazen, brez kulturnih vrednot in etosa. Nekaj dni za Zornom je v Delu objavil članek o nagrajencu tudi Jože Hradil. V prispevku Imre Kertész ne priznava usode, prisega na svobodo je najprej opozoril na to, da je bil Kertesz na Madžarskem slabo poznan, necenjen, strokovno ignoriran, celo zavrnjen in namenoma preslišan. Tudi roman Brezusodnost so ob izidu zavrnili. Drugače, pravi Hradil, je bilo po Evropi, kjer so to pripoved prevajali, še preden je bila nagrajena. V nadaljevanju popiše Kertészova glavna dela in premisli nagrajeno. Tu opozori, da ne gre toliko za tematiziranje nacističnih grozot, ki jih doživlja židovski deček, ampak za doživljanje trpljenja kot takega; za obsodbo ter predvsem za opozorilo, da zgodovine ni mogoče spregledati in je zato soočenje z njo nujno. Preseganje antisemitizma, nacionalizma in vseh drugih ideoloških zablod pa je lahko le posledica dialoga s preteklostjo. Na koncu Hradil pojasni, da Kertészova univerzalnost nastaja iz pisateljeve organske povezanosti z židovstvom na eni strani ter integracije $\mathrm{v}$ madžarski kulturni prostor na drugi.

Leta 2003 je Bernard Nežmah v Mladini, v članku Madžarski nobelovec židovskega rodu o svoji izkušnji Auschwitza in Buchenwalda pisal o Brezusodnosti Imreta Kertésza. V romanu je našel grozo počasnega, zanesljivega umiranja ter vdanost $\mathrm{v}$ usodo, ki ne zmore niti sovraštva niti žalosti in ne prošnje. Tega leta je Jože Hradil k prevodu romana Imreta Kertésza Kadiš za nerojenega 
otroka napisal spremno besedo in $\mathrm{v}$ njej povzel pisateljeve glavne romane o holokavstu. Najprej je pojasnil recepcijo romana Brezusodnost na Madžarskem in po svetu ter opozoril, da so ob njegovem izidu leta 1975 madžarski literarni kritiki delo prezrli zaradi avtorjevega židovstva, odnos do romana pa se je po Hradilovem mnenju spremenil šele z Nobelovo nagrado. V delu se mu zdi pomembno dvoje: prvič, sporočilo, da grozote ne prihajajo le od znanega sovražnika, v tem primeru od nacistov, ampak tudi od sojetnika, in drugič, da pripovedovalca ne zanima verističen opis dogodkov, ki bi delovali $\mathrm{s}$ svojo neposredno grobostjo, ampak je učinek drugje - v intimnih in celo liriziranih detajlih. Tudi roman Kadiš za nerojenega otroka je avtobiografski, pravi Hradil, ker poleg tematike holokavsta zajema še pripovedovalčeve spomine na družino in šolsko vzgojo, ki da se je mnogokrat usodno sprevračala $v$ dresuro. Delo se od Brezusodnosti slogovno močno loči, saj pripoved v dolgih povedih, te se včasih nadaljujejo skozi več strani, sledi toku zavesti. Istega leta je o Brezusodnosti pisal še Dražen Dragojević, in sicer v spremni besedi Hradilovega prevoda. Pojasnil je, da je pri razumevanju Kertészovih del nujno potrebno upoštevati družbene razmere na Madžarskem. Roman pa po njegovem ne govori o žrtvah in zločincih, ampak o človeku, ne gre za Nemce, naciste, za koncentracijska taborišča, prav tako ne za Žide, za jetnike, ampak za zlo, ki je del sveta. Vprašanje torej niso vojni zločini, ampak, kako se izogniti zlu, v Brezusodnosti namreč ne vidi slike preteklosti, ampak sporočilo sedanjosti.

Jutka Rudaš je leta 2004 ponovno pisala o madžarskem pisatelju Esterházyju; za znanstveno revijo Jezik in slovstvo je pripravila članek z naslovom Esterházy pri nas. Delo madžarskega pisca ji pomeni pomemben idejni in problemski premik v dinamiki madžarske pripovedne proze in korpus, ki je svoj presežek dal s »stilistično revolucijo« jezika. Za avtorico je nov način pisanja ${ }^{8}$ najbolj izčiščen v Proizvodnem romanu. Rudaševa Esterházyja uvršča v sam vrh madžarske in evropske literature, kar utemeljuje z dejstvom, da njegova dela prevajajo $\mathrm{v}$ številne tuje jezike, za literarno ustvarjanje pa je prejel kar petnajst prestižnih nagrad. V nadaljevanju se Rudaševa ukvarja z romanom Harmonia Caelestis. Označi ga kot zgodovinsko-družinski roman in pojasni njegovo dvodelno zgradbo: prvi del je fragmentarna pripoved $\mathrm{z}$ radikalnim jezikom, kar deluje dekonstruktivno in nadosebno, drugi je enotnejši, epski, jezikovno tradicionalnejši in evocira osebni vidik. Avtorica v romanu najde ubrano strukturo fiktivnega in imaginarnega ter dejanskega in historičnega. Esterházyjev referenčni horizont po njenem mnenju zahteva od bralca solidno poznavanje madžarske zgodovine in kulture, pisateljeve asociacije, številni citati in filozofske interpretacije pa prevajalcu postavljajo resno oviro.

Intervju z Esterházyjem je leta 2005 pripravil tudi Mladen Pavičić, in sicer $\mathrm{z}$ naslovom Prilesti iz brezna, ki se mu pravi jaz. Objavljen je bil v reviji Emzin. Pavičić v pogovoru izpostavi pisateljev vpliv na spremembo paradigme

\footnotetext{
${ }^{8}$ Esterhazyjev slog je po mnenju Jutke Rudaš »poln citatov, polcitatov, samocitatov, intertekstov, izpustov, zamolkov, nedokončanih povedi z močno kulturno tradicijo«. Estrhazy po njenem dosega humor in ironijo z različnimi besednimi kombinacijami.
} 
madžarske proze okoli leta 1980. Poudari, da avtor pri pisanju izhaja iz jezika in s tem evocira estetsko plast literature, kar je povzročilo negativen odziv madžarskih kritikov, ki so v smislu socrealistične estetike pričakovali jasno in k didaktičnemu koncu zasnovano zgodbo. Dalje pri Esterházyju prepozna poudarjeno parodijo, interes za zgodovino, naslanjanje na biografske podatke. Pronicljiva je ugotovitev, da je Esterházyjev Uvod v leposlovje začetek realizacije pisateljevega specifičnega, rekli bi skoraj ontološkega pogleda na svet, literaturo in jezik. Bralec izve tudi, da je pisatelj v romanu Harmonia Caelestis upovedil večstoletno zgodovino svoje družine in si pri tem prizadeval za simbiotično zvezo zgodovinsko preverljivih dejstev s fikcijo. Končno Pavičić v Esterházyjevih delih prepozna številne citate, ki da prek koncepta medbesedilnosti namigujejo na postmodernizem.

Naslednje leto je Jože Hradil v Delu objavil prispevek z Imretom Kertészom Lov za nobelovcem in zgrešena poanta. Avtor po svojem kratkem srečanju z nagrajencem zapiše, da $\mathrm{v}$ romanu ni pomembna židovska problematika niti ne nacizem in fašizem, prav tako pisatelja ne zanimata ta ali ona politična opcija ali ideološki koncept, narodna pripadnost $\mathrm{v}$ pomenu ujetosti, ampak gre za globlje in usodnejše ugotovitve: za problem zla kot takega.

Leta 2006 je Jutka Rudaš v časniku Dnevnik pisala o Pétru Nádasu. V članku $\mathrm{z}$ naslovom Vzporedna življenja je $\mathrm{v}$ pisateljevem romanu Vzporedne zgodbe ugotovila, da Nádasev literarni svet tvorijo zgodovinske refleksije in subtilna ter večplastna analiza odtujenega človeka. Avtorice tako ne preseneča, da v pisateljevem svetu ni dialoga, ni ljubezni, erotika pa se spremeni v orgiastično divjanje brez užitka.

Leta 2008 je k slovenskemu prevodu Nádasevih besedil Lastna smrt in Skrbna opredelitev kraja Mladen Pavičić napisal spremno študijo in predstavil umetnikovo literarno ustvarjanje. Interpretacija posameznih del pisca privede do spoznanja o tem, da je pomembna motivno-tematska struktura, ki v različnih variantah (lastna smrt, nasprotje posameznika in družbe, stalinizem na Madžarskem, holokavst, homoseksualnost, konflikt telesnosti ter duševnosti) utripa v mnogih umetnikovih besedilih, smrt. Razloge za to in za Nádasev izrazito pesimističen odnos do sveta prepozna v pisateljevih spominih, kamor spadajo eksplozija bombe nad domačo hišo, montirani proces proti očetu, očetov samomor, materina smrt, bolezen, politične napetosti, ki leta 1956 prerastejo v ostre spopade, življenje v internatu itd. Problemski sklopi, o katerih piše Péter Nádas, po Pavičićevem mnenju pustijo opazne posledice na področju jezika in sloga, tu je mogoče najti vulgarizme, ki močno destruirajo njuno estetsko podobo. Istega leta je o Nádasu pisala tudi Jutka Rudaš, in sicer v časopisu Dnevnik. V kratkem poročilu je opozorila, da se omenjeni madžarski pisatelj odlikuje po drzni literarizaciji spolnosti in telesnosti. Nekaj dni za tem je ista avtorica v Dnevniku objavila tudi obsežen intervju s Pétrom Nadásem. Njegov naslov je Zakaj je pravzaprav treba končati roman? Pisatelja je predstavila kot ustvarjalca, ki je s Knjigo spominov leta 1986 »postavil mejnik v zgodovini madžarske proze«. Intervju odgovori na nekatera bistvena vprašanja o Nadásevi ustvarjalnosti. Tako bralec spozna pisateljev odnos do judovstva, fašizma in 
rasizma, zve, zakaj ga vznemirjajo seksualnost, pornografija in erotika, seznani pa se tudi z njegovimi pogledi na samo umetniško ustvarjanje, na problem uspeha ter na etične vrednote in moralne zakonitosti. Konec leta 2008 je Jutka Rudaš v Delu pod naslovom Življenje kot histerični molk objavila še kratek članek o zbirki novel Okraj Sinistra Ádáma Bodorja in med drugim zapisala, da človek v Bodorjevih novelah preživlja odtujenost in čutno ter čustveno krizo, ki onemogočajo zagone $\mathrm{v}$ smeri perspektive.

4 Kot bralec literarnozgodovinskih razprav, kritik in ocen ter poročil o madžarski literaturi, ki se zaveda, da je vsak od upoštevanih spisov tudi rezultat subjektivnih presoj in so nekateri ustvarjalci ali dela iz različnih razlogov lahko spregledani, ugotavljam, da so pisci sosednjo literaturo slovenskemu bralcu kljub mojim začetnim pomislekom vendarle približali; in reči je treba, da posebej v zadnjih letih stvari potekajo bolj dosledno, kot je to bilo včasih. $\mathrm{Ne}$ nazadnje med opisanimi ustvarjalci in njihovimi deli niso le lavreati in nagrajena dela, refleksija madžarske književnosti upošteva tudi mlajše in manj znane avtorje. Bistveno pa se mi zdi to, da uvidi v slovstvo sosednjega naroda učijo, da je ta književnost, podobno kot nekatere druge postsocialistične, po letu 1980 doživela temeljite premike. Verjetno ni pretirana ocena, da je šlo za določeno osvobajanje znotraj ustvarjalnega polja. Kakor koli, literarna kritika in literarna zgodovina sta v madžarski književnosti opazili, da:

- problemska plast tega slovstva kaže literarizacijo bivanjskih vprašanj, katerih osnova je prej ali slej odtujenost;

- narativni vidik opozarja na posebno razmerje med pripovedovalcem in upovedovano snovjo, tu mislim na sproščenost, ki brez strahu zaradi odsotnosti pozitivne ideje lahko posega tudi po cinizmu ali preigrava različne absurdne situacije;

- slogovno področje kaže uspešno realizacijo postopkov, kjer prihajajo do izraza tako poetična, emotivna, referencialna in metajezikovna funkcija jezika ${ }^{9}$ kot tudi različne destruktivne variante, dehierarhizacija ter »inteligentna« destrukcija.

Povedano gotovo pomeni tisto vsebinsko podlago, ki ob siceršnji literarni kompetenci omogoča kolikor toliko celovito sledenje temu korpusu.

Tudi če sprejemanje književnega dela poteka $\mathrm{v}$ pogojih, kjer informacij, ki prihajajo od umetnine, ni mogoče povezati z nobenimi kulturnimi, zgodovinskimi ali civilizacijskimi ter literarnimi podatki o okoliščinah nastanka, in, seveda če ne obstaja jezikovna ovira, bo komunikacija med besedilom in bralcem stekla. Vendar ne mislim na to, ampak na nekaj drugega. Prvi aspekt, ki sem ga omenil, je literarni, saj gre za vprašanje bralčevega vedenja o drugem slovstvu, za njegova pričakovanja in predvidevanja; ne nazadnje za stopnjo

\footnotetext{
${ }^{9}$ Terminologijo povzemam po razpravi Romana Jakobsona iz leta 1960 Linguistics and poetics.
} 
njegove literarne vključenosti. Drugi, po moje celo pomembnejši, pa prek medsebojnega književnega poznavanja dveh narodov opozarja na problem stikov in vzajemnosti, spoštovanja ter enakovrednosti. Če združena Evropa ni zgolj projekt altruističnih zanesenjakov ter ob misli, da so prava globinska evropska stičišča tam, kjer prihajajo pred nas narodne, na stari celini zgodovinsko močno ukoreninjene ter občutljive zadeve, vezane na duhovne in kulturne ter jezikovne potenciale, potem so prav podatki, o katerih sem pisal, odličen pokazatelj, do katere stopnje $\mathrm{v}$ približevanju smo prišli.

\section{LITERATURA}

Davis Robert MURAY, 2001: Položaj madžarske literature v devetdesetih. Sodobnost 65/7-8, 935-951.

Dragan DRAGOJEVIČ, 2003: Spremna beseda. Brezusodnost. Ljubljana: Študentska založba.

Zsolt FARKAS, 2001: Sodobna madžarska proza. Sodobnost 65/7-8, 891-902.

Jože FILO, 1992: Kratek oris madžarske književnosti. Zbornik slavističnega društva. Ljubljana: Zavod RS za šolstvo in šport. 238-252.

- -, 1992: Slovenci in madžarska književnosti. Zbornik slavističnega društva. Ljubljana: Zavod RS za šolstvo in šport. 223-235.

Gabriela GAAL, 1998: Ima svet konstrukcijo? Razgledi 18/1121, 6-8.

Jože HORVAT, 1992: Pesnik kot državljan. Slovenec 76/225, 21.

- -, 2002: Imre Kertesz ne prizna usode, prisega na svobodo. Delo 44/249, 4.

- -, 2003: Spremna beseda. Kadiš za nerojenega otroka. Radovljica: Didakta.

- -, 2005: Tudi med manj znanimi so odlični pisatelji. Delo 47/32, 11.

- -, 2006: Lov za nobelovcem in zgoščena poanta. Delo 48/121, 23.

Endre KARÁTSON, 2004: Komu pišemo? Apokalipsa 86, 156-165.

Marjanca MIHELIČ, 1994: Vodnik po Esterházyu. Nova revija 11/121, 552-557.

- -, 1992: Madžarska proza devetdesetih. Literatura 4/34, 80-88.

--, 1999: Spremna beseda. Konec družinskega romana. Murska Sobota: Pomurska založba.

--, 1999: Roman lanskoletnega vileniškega lavreata v slovenščini. Delo 41/209, 19.

- -, 2007: Bolj kot estetika izgrajevanja nas določa estetika uničevanja. Delo 49/228, 19.

Mladen PAVIČIĆ, 2002: Je letošnji nobelovec sploh madžarski pisatelj? Delo 44/249, 3.

- -, 2005: Prilesti iz brezna, ki se mu pravi jaz. Emzin 15/1, 28-31. 
_-, 2008: Ta knjiga je nevarna! Lastna smrt / Skrbna opredelitev kraja. Ljubljana: Študentska založba.

Jutka RUDAŠ, 2000: Slovenija v Nebeški harmoniji Esterházyevih. Delo 42/107, 18.

- -, 2004: Esterházy pri nas. Jezik in slovstvo 49/1, 17-27.

- -, 2006: Vzporedna življenja. Dnevnik 56/246, 7.

- -, 2008: Tuji gosti na Festivalu zgodbe - Fabula. Dnevnik 58/16, III.

- -, 2008: Življenje kot histerični molk. Delo 50/235, 26.

- -, 2008: Zakaj je pravzaprav treba končati roman? Dnevnik 58/20, 17.

Aleksander ZORN, 2002: Slavni madžarski pisatelj. Delo 44/235, 1.

\section{LITERARY-HISTORICAL AND LITERARY-CRITICAL REFLECTION OF HUNGARIAN LITERATURE IN THE SLOVENE LANGUAGE AFTER THE YEAR 1980}

The acceptance of literary works inevitably follows from the extent of previous knowledge, which directs the degree and the amount of the reader's readiness for reception. Theories claiming that "previous knowledge", in the sense of agreed forms of meaning, contaminates the recognition of information offered by the literary work, cannot be of essential importance; it is, however, important to acknowledge that the acceptance of the literary work is more total if the reader knows some of the circumstances of its origin and is acquainted with at least some the most important features of the literature to which the text belongs to.

The research results from the literary-historical and literary-critical reflection on Hungarian literature in the Slovene environment and the question of the $t$ kind of the knowledge horizon accompanying translations of Hungarian literary works and the literary competence of the readership, confirm the hypothesis that Slovenes do not know much about the neighbouring literature. According to this finding, we must take into consideration that the literature in question is not among the major literatures; we must also consider the fact that a relatively small number of Slovenes speak Hungarian. It is also true, however, that the Hungarians are a nation to which we are historically connected; we have to consider both the minorities and the fact that Hungarian literature is important not only because of the Nobel Prize winner, but also as a corpus with many authors deserving of literary recognition. In judging the situation, we can also depend on the good organization of minority education and such matters. In accordance with this information, the discovery that there exist only a few writers who systematically acquaint Slovene readers with the most important events in Hungarian literature is really surprising. The material reviewed has also shown that the first contacts of Slovenes with Hungarian literature took place in the 20th century, that they were more frequent after the Second World War and that in recent years they have been mostly improving. 